\title{
ISOLASI DAN KARAKTERISASI AKTIVITAS \\ AMILOGLUKOSIDASE DARI KAPANG ASAL LIMBAH CAIR TAPIOKA
}

\author{
Hafsan*, Maslan, Eka Sukmawaty \\ Jurusan Biologi \\ Fakultas Sains dan Teknologi UIN Alauddin Makassar \\ Jl. Sultan Alauddin No. 63, Kabupaten Gowa, Sulawesi Selatan. 92113 \\ "E-mail: hafsan.bio@uin-alauddin.ac.id
}

\begin{abstract}
Abstrak: Penelitian ini bertujuan untuk mengetahui keberadaan isolat kapang dari limbah cair tapioka yang memiliki aktivitas amilolitik dan amiloglikosidase yang dihasilkan kapang tersebut. Parameter penelitian ini adalah indeks amilolitik isolat kapang dengan menggunakan metode pati agar, dan aktivitas amiloglukosidase yang dilakukan dengan metode Somogyi pada suhu dan $\mathrm{pH}$ yang ditentukan. Isolat dan aktivitas amiloglukosidase dianalisis secara deskriptif. Hasil penelitian menunjukkan bahwa pada limbah cair tapioka berhasil diisolasi kapang penghidrolisis pati sekaligus penghasil amiloglukosidase yang diidentifikasi sebagai Rhizopus oryzae, Aspergillus oryzae, A. niger dan Penicillium sp. Aktivitas amiloglukosidase dari keempat isolat memiliki karakteristik yang berbeda dengan aktivitas tertinggi dihasilkan oleh $A$. niger dengan pertumbuhan optimum pada suhu $45^{\circ} \mathrm{C}$ dan eksponen ion hidrogen 4,$0 ; R$. oryzae optimum pada suhu $40^{\circ} \mathrm{C}$ dengan $\mathrm{pH}$ 4,5 sedangkan $A$. oryzae optimum pada suhu $40^{\circ} \mathrm{C}$ dengan $\mathrm{pH} 4,0$ dan Penicillium sp. yang optimum pada suhu $45^{\circ} \mathrm{C}$ dengan dua $\mathrm{pH}$ optimum yaitu 4,5 dan 5,5 .
\end{abstract}

Kata Kunci: amiloglukosidase, Aspergillus, kapang, Penicillium, Rhizopus

\section{PENDAHULUAN}

$\mathbf{U}$

bi kayu yang dihasilkan di Indonesia sebagian besar dimanfaatkan sebagai bahan baku tapioka. Proses pengolahan ubi kayu menjadi tapioka tersebut menyisakan limbah yang masih kaya akan karbohidrat $( \pm 50 \%)$ dan bahan organik lainnya seperti gula dan protein (Dwi, 2017; Rahayu et al., 2019). Limbah tersebut berpotensi digunakan sebagai substrat pertumbuhan kapang untuk membentuk biomassa dan membentuk metabolit-metabolit seperti enzim. Kapang menghasilkan enzim intraseluler dan ekstraseluler untuk keperluan metabolisme. Enzim ekstraseluler umumnya dihasilkan untuk melaksanakan peran dalam siklus metabolik kapang itu sendiri (asimilasi), misalnya untuk memecah polimer/makromolekul menjadi molekul yang lebih kecil agar dapat melewati membran sel mikroba seperti amiloglukosidase yang dikeluarkan oleh kapang untuk memecah substrat pati menjadi monomer glukosa (Sopandi \& Wardah, 2014; Adnyana et al., 2015). Di sisi lain amiloglukosidase mempunyai nilai ekonomi dan digunakan secara meluas dalam industri makanan, minuman, detergen dan farmasi (Sunaryanto \& Marasabessy, 2016).

Amiloglukosidase dikenal pula dengan nama glukoamilase atau $\alpha$-1,4-glukan glukohidrolase merupakan enzim penghidrolisis pati langsung menjadi glukosa yang 
banyak digunakan dalam industri makanan dan minuman (seperti gula cair sebagai sirup glukosa) yang digunakan untuk sakarifikasi dari pati, dekstrin atau glukosa. Amiloglukosidase mengkatalisis pemutusan ikatan glikosida $\alpha-1,4$ dan $\alpha-1,6$ dalam reaksi hidrolisis amilosa, amilopektin, dan glikogen dari bagian ujung gula secara berurutan (Nangin \& Sutrisno, 2015; Sutikno et al., 2016). Enzim ini mampu dihasilkan oleh berbagai jenis kapang antara lain Aspergillus niger, A. satoi, P. oxalium, Rhizopus dan beberapa jenis khamir (Melliawati et al., 2006).

Melihat kegunaan dari amiloglukosidase yang luas, maka pengusahaan serta penyediaan enzim tersebut akan sangat menguntungkan bila dapat dihasilkan dengan cara yang murah dan mudah. Mikroorganisme dalam hal ini kapang dapat digunakan sebagai inokulan sumber penghasil amiloglukosidase karena mempunyai nilai lebih yaitu dapat dihasilkan dalam jumlah yang besar dibandingkan dengan mengisolasi enzim dari hewan maupun tumbuhan. Selain itu kapang dapat tumbuh dan berkembang pada substrat yang terdiri dari komponen limbah atau sisa produksi pengolahan industri pangan termasuk limbah cair tapioka yang merupakan salah satu sisa dari proses pembuatan tapioka yang sangat potensial digunakan untuk produksi enzim karena masih mengandung komponenkomponen nutrisi yang diperlukan untuk suatu pertumbuhan mikroorganisme terutama kapang, sekaligus pemanfaatan limbah yang terbuang percuma (Nugroho et al., 2016; Karunawan et al., 2017; Indrianeu et al., 2019 ).

Potensi pemanfaatan kapang sebagai sumber enzim, yakni amiloglukosidase maka perlu dilakukan pencarian informasi mengenai aktivitas metabolisme mikroorganisme, seleksi biakan yang berpotensi memproduksi metabolit dengan produktivitas tinggi, menentukan kondisi optimum untuk pertumbuhan mikroorganisme maupun kondisi optimum untuk aktivitas hasil metaboliknya. Sehubungan dengan uraian tersebut, maka dilakukan penelitian untuk mengungkap karakteristik aktivitas amiloglukosidase dari kapang yang diisolasi dari limbah cair tapioka, mengingat bahwa pada limbah cair tapioka kaya akan nutrisi yang diperlukan oleh kapang untuk pertumbuhan dan pembentukan enzim. Prinsipnya, penelitian ini bertujuan untuk mengetahui keberadaan isolat-isolat kapang asal limbah cair tapioka yang memiliki aktivitas amilolitik dan aktivitas amiloglukosidase.

\section{METODE PENELITIAN}

Penelitian ini merupakan penelitian deskriptif eksploratif yang dilakukan dengan mengisolasi kapang dari limbah cair tapioka kemudian diisolasi dan ditentukan aktivitas amiloglukosidase yang dihasilkannya. Sampel limbah cair tapioka berasal dari salah satu pabrik pengolahan tapioka di Kabupaten Gowa.

Alat-alat yang digunakan dalam penelitian ini adalah: cawan Petri, tabung reaksi, rak tabung, erlenmeyer, autoklaf, oven, inkubator, corong, penangas, gelas ukur, pipet volum, spoit, sentrifuge, shaker, neraca analitik, jarum inokulasi (ose), lemari pendingin, botol pengenceran, termometer, buret, laminar air flow (LAF), gelas piala, water bath, dan $\mathrm{pH}$ meter. Sedangkan bahan yang digunakan adalah: limbah cair tapioka, aquades, alkohol 70\%, PDA, soluble starch, larutan JKJ, yeast ekstrak, $\mathrm{H}_{2} \mathrm{SO}_{4} 2 \mathrm{~N}, \mathrm{Na}_{2} \mathrm{~S}_{2} \mathrm{O}_{3}$, $\mathrm{MgSO}_{4}, \mathrm{MgSO}_{4} .7 \mathrm{H}_{2} \mathrm{O},\left(\mathrm{NH}_{4}\right)_{2} \mathrm{SO}_{4}, \mathrm{KCl}, \mathrm{CaCl}_{2}, \mathrm{CuSO}_{4}, \mathrm{KI}, \mathrm{KIO}_{3} \mathrm{0}, 1 \mathrm{~N}, \mathrm{Na}_{2} \mathrm{CO}_{3}$, $\mathrm{K}_{2} \mathrm{C}_{2} \mathrm{O}_{4}, \mathrm{HCl} 1 \mathrm{~N}, \mathrm{NaOH} 1 \mathrm{~N}$, aluminium foil dan kapas.

Pengambilan data meliputi 6 tahap yaitu: 1) Sterilisasi alat dan bahan; 2) Pembuatan medium; 3) Isolasi dan penapisan kapang; 4) Produksi amiloglukosidase; 5) Isolasi amiloglukosidase; dan 6) Pengukuran aktivitas amiloglukosidase. 
- Sterilisasi alat dan bahan: semua alat yang digunakan dicuci hingga bersih, kemudian dikeringkan. Alat-alat yang tahan panas dibungkus dengan kertas dan disterlkan dalam oven pada $160-180^{\circ} \mathrm{C}$ selama 2 jam. Medium dan alat-alat yang tidak tahan suhu tinggi disterilkan dalam autoklaf pada suhu $121^{\circ} \mathrm{C}$ selama 15 menit pada tekatan 2 atm sesuai prosedur dari Hadioetomo (1990) serta Lay \& Hastowo (1994).

- Pembuatan medium dan pereaksi uji aktivitas amiloglukosidase: medium meliputi pembuatan medium Potato Dekstrosa agar (PDA), medium agar amilum, dan medium starter, serta medium produksi enzim. Sedangkan pereaksi uji aktivitas amiloglukosidase meliputi: pereaksi Shaffer Somogyi, larutan iod oksalat, larutan standar $\mathrm{Na}$ tiosulfat $\left(\mathrm{Na}_{2} \mathrm{~S}_{2} \mathrm{O}_{3}\right) 0,005 \mathrm{~N}$, dan larutan pati $2 \%(\mathrm{~b} / \mathrm{v})$.

- Isolasi dan penapisan kapang: Sampel limbah cair tapioka berasal dari pabrik tepung tapioka PT. Katelindo Tulus Sejahtera di Kecamatan Bontomarannu Kabupaten Gowa Sulawesi Selatan dimasukkan ke dalam botol steril dan langsung dibawa ke laboratorium. Isolasi kapang dilakukan dengan menggunakan media agar amilum. Sebanyak $10 \mathrm{ml}$ sampel limbah cair tapioka dimasukkan ke dalam botol pengencer berisi aquades steril $90 \mathrm{ml}$ (pengenceran $10^{-1}$ ) sampai pengenceran $10^{-5}$. Dari hasil pengenceran terakhir, sampel dipipet ke dalam cawan petri yang berisi media padat kemudian disebar agar sampel merata dengan menggunakan gelas bengkok. Inkubasi dilakukan pada suhu $30^{\circ} \mathrm{C}$ selama $3 \times 24 \mathrm{jam}$. Isolat yang tumbuh dimurnikan pada media dengan komposisi yang sama. Warna, bentuk dan ciri-ciri morfologi kapang diamati untuk keperluan identifikasi. Masing-masing isolat kemudian ditetesi larutan JKJ di sekitar tepi koloni kapang. Zona bening yang terbentuk di sekeliling koloni menunjukkan bahwa kapang tersebut memiliki aktivitas amilolitik. Selanjutnya kapang tersebut diisolasi pada media PDA miring sebagai isolat untuk kemudian dikarakterisasi amiloglukosidasenya.

- Produksi amiloglukosidase: Penentuan aktivitas amiloglukosidase dilakukan terhadap isolat kapang yang memiliki rasio amilolitik (aktivitas amilolitik). Isolat kapang tersebut (umur 7 hari) yang terlebih dahulu diinokulasikan ke dalam medium starter dan diinkubasi selama 24 jam, sebanyak $10 \mathrm{ml}$ dimasukkan ke dalam medium produksi steril kemudian diinkubasi pada suhu $30^{\circ} \mathrm{C}$ dengan kecepatan $180 \mathrm{rpm}$ selama 3 x 24 jam (Xiao et al., 2006).

- Isolasi amiloglukosidase: Kultur yang diperoleh dari medium produksi disentrifugasi pada kecepatan $3000 \mathrm{rpm}$ selama 15 menit. Selanjutnya filtrat (supernatan) didekantasi yang merupakan ekstrak kasar enzim amiloglukosidase. Ekstrak enzim kasar inilah yang selanjutnya diuji aktivitasnya.

- Pengukuran aktivitas amiloglukosidase: Penentuan aktivitas amiloglukosidase didasarkan atas perhitungan gula pereduksi sebagai glukosa yang dihasilkan dari aktivitas enzim terhadap substrat. Filtrat (ekstrak kasar enzim amiloglukosidase) yang diperoleh dari isolasi enzim dipipet sebanyak 2,5 $\mathrm{ml}$ ke dalam erlenmeyer kemudian ditambahkan larutan pati $2 \%$ sebanyak $5 \mathrm{ml}$. Nilai $\mathrm{pH}$ diatur sesuai $\mathrm{pH}$ pengujian $(3,0$; $3,5 ; 4,0 ; 4,5 ; 5,0 ; 5,5 ; 6,0 ; 6,5 ; 7,0)$ pada suhu pengujian $(20,25,30,35,40,45,50$, $55,60^{\circ} \mathrm{C}$ ) dengan menggunakan water bath selama 30 menit. Kemudian enzimnya diinaktifkan pada suhu $80^{\circ} \mathrm{C}$ selama 10 menit. Kemudian dilakukan analisis gula pereduksi dengan metode Shaffer Somogyi (Xiao et al., 2006; Vinet \& Zhedanov, 2010; Devitria \& Sepriyani, 2018) sebagai berikut; sebanyak $5 \mathrm{ml}$ larutan contoh dipipet ke dalam erlenmeyer kemudian ditambahkan $5 \mathrm{ml}$ larutan Shaffer Somogyi dan dikocok. Blanko disiapkan dengan menggunakan aquades dan ditambakan $5 \mathrm{ml}$ 
larutan Shaffer Somogyi. Labu ditutup dan dipanaskan dalam penangas air mendidih selam 15 menit. Secara hati-hati labu diangkat dan didinginkan selama 4 menit di dalam water bath, setelah itu tutup labu dibuka, melalui dinding labu ditambahkan 2 $\mathrm{ml}$ iod oksalat dan $3 \mathrm{ml} \mathrm{H}_{2} \mathrm{SO}_{4} 2 \mathrm{~N}$. Isi labu dikocok sampai endapan merah bata hilang dan didiamkan selam 5 menit di dalam bak pendingin dan selanjutnya dititrasi dengan menggunakan $\mathrm{Na}_{2} \mathrm{~S}_{2} \mathrm{O}_{3} 0,005 \mathrm{~N}$ dengan indikator pati.

- Teknik pengumpulan data: data diperoleh dengan cara mengisolasi dan menentukan aktivitas amiloglukosidase dari kapang asal limbah cair tapioka. Penentuan aktivitas amiloglukosidase yang yang dihasilkan oleh masing-masing isolat kapang asal limbah cair tapioka tersebut ditentukan berdasarkan persamaan berikut:

\section{Mg dekstrosa x fp x 1000}

$\mathbf{A E}=$

\section{Keterangan:}

AE

Fp

Mg dekstrosa

VE

$\mathbf{t}$

$\begin{aligned} & \mathbf{1 8 0} \mathbf{x} \text { VE } \mathbf{x ~ t} \\ = & \text { Aktivitas enzim (unit } / \mathrm{ml} / \text { menit }) \\ = & \text { Faktor pengenceran } \\ = & 0,1099(\mathrm{ml} \text { blangko }-\mathrm{ml} \text { titran })+0,048 \\ = & \text { Volume enzim }(\mathrm{ml}) \\ = & \text { Waktu inkubasi (menit) }\end{aligned}$

Satuan aktivitas amiloglukosidae dinyatakan dalam unit/ml ekstrak enzim. Satuan unit aktivitas enzim setara dengan satu $\mu \mathrm{M}$ glukosa yang dihasilkan dalam hidrolisis substrat yang dikatalisis oleh amiloglukosidase dalam $1 \mathrm{ml}$ enzim kasar permenit. Data yang diperoleh dianalisa secara deskriptif, yaitu dengan penentuan rerata dan penyajian melalui diagram hubungan antara aktivitas amiloglukosidase pada variasi suhu dan $\mathrm{pH}$.

\section{HASIL DAN PEMBAHASAN}

Sebanyak empat isolat kapang telah diisolasi dari limbah cair tapioka yang merupakan penghidrolisis pati yang ditandai dengan terbentuknya zona bening di sekitar koloni setelah ditetesi larutan JKJ (Gambar 2). Keempat isolat yang tumbuh memiliki rasio amilolitik yang berbeda-beda (Tabel 1). Rasio amilolitik dihitung berdasarkan hasil bagi diameter zona bening terhadap diameter koloni.

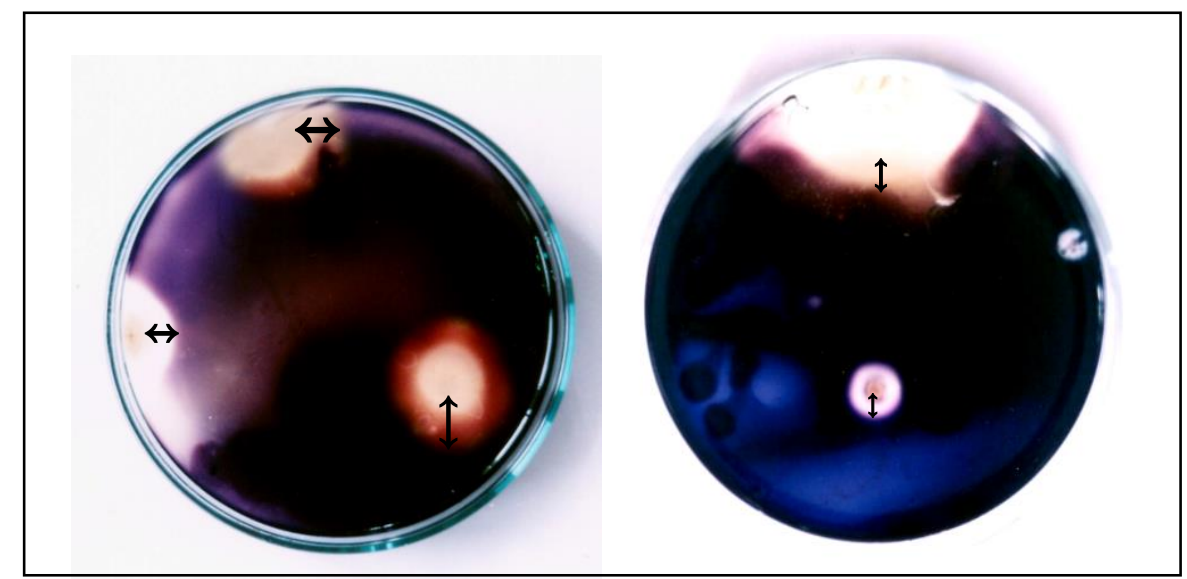

Gambar 2. Koloni kapang asal limbah cair tapioka yang memiliki aktivitas amilolitik yang ditandai terbentuknya zona bening di sekitar koloni (tanda $\leftrightarrow$ ) 
Tabel 1. Rasio amilolitik kapang hasil isolasi pada masa inkubasi 3 × 24 jam pada suhu $30^{\circ} \mathrm{C}$

\begin{tabular}{lccc}
\hline Isolat & Diameter koloni $(\mathbf{c m})$ & Diameter zona bening $(\mathbf{c m})$ & Rasio amilolitik \\
\hline Isolat A & 1,9 & 2,6 & 1,37 \\
Isolat B & 0,3 & 0,7 & 2,25 \\
Isolat C & 0,4 & 1,5 & 3,75 \\
Isolat D & 1,1 & 1,4 & 1,27
\end{tabular}

Keberadaan substrat berupa pati tapioka dalam media produksi menginduksi sintesis enzim ekstraseluler dari kapang berumur 7 hari. Hal ini karena substrat yang berberat molekul tinggi seperti pati akan sulit masuk ke dalam sel, sehingga perlu dipecah terlebih dahulu oleh enzim misalnya amiloglukosidase yang menghasilkan produk akhir berupa glukosa dari aktivitasnya. Aktivitas amiloglukosidase yang terukur dari masingmasing isolat ditunjukkan pada Gambar 2.

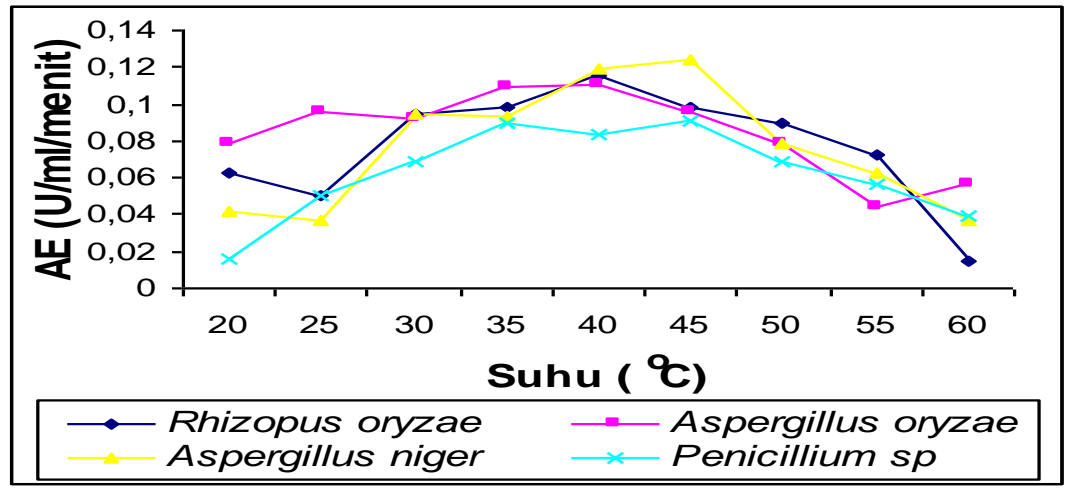

Gambar 2. Hubungan antara aktivitas amiloglukosidase dengan variasi suhu pengujian

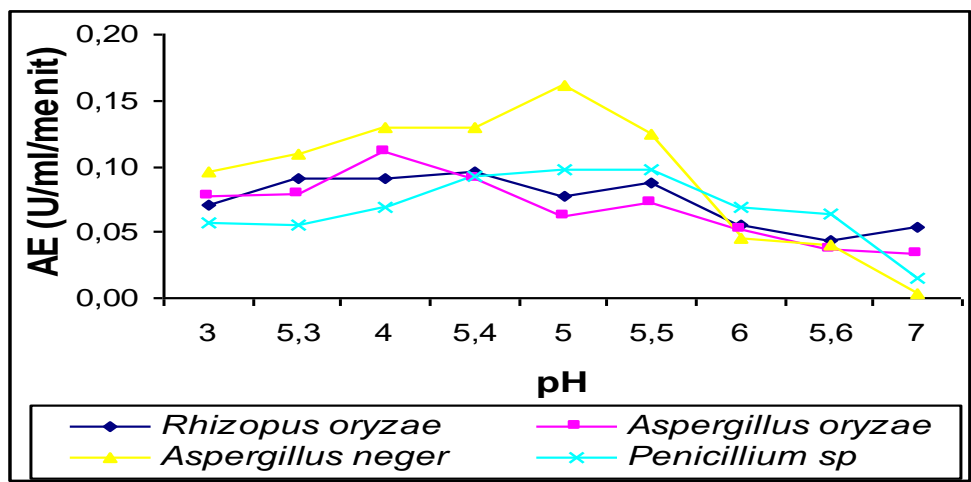

Gambar 3. Hubungan antara aktivitas amiloglukosidase dengan variasi pH pengujian

Keempat isolat kapang yang diperoleh dari limbah cair tapioka memiliki aktivitas amilolitik yang berbeda-beda. Berdasarkan pengamatan warna dan bentuk koloni serta ciri-ciri morfologi kapang pada media agar dan preparat slide kultur, keempat isolat A, $\mathrm{B}, \mathrm{C}$ dan D masing-masing diidentifikasi sebagai $R$. oryzae, A. oryzae, A. niger dan Penicillium sp.

Rasio amilolitik tertinggi dimiliki oleh isolate $A$ niger meskipun diameter koloninya lebih kecil dibandingkan dengan ketiga isolat lainnya, dimana setelah penentuan aktivitas amiloglukosidase menunjukkan aktivitas tertinggi dibandingkan isolat yang lain. Hal ini dipengaruhi oleh kesuburan A. Niger yang lebih rendah, sehingga kemampuannya menghidrolisis pati menjadi lebih tinggi karena energi yang dihasilkan dari respirasi untuk pembentukan miselium, sebagaimana menurut Ilmi \& Kuswytasari (2013), bahwa 
kesuburan kapang yang tinggi menyebabkan produktivitas enzim kapang tersebut menjadi lebih rendah, karena energi yang dihasilkan dari respirasi lebih banyak digunakan untuk pembentukan miselium sehingga memengaruhi jumlah enzim yang dihasilkan oleh suatu kapang (Pedersen et al., 2000). Namun ketiga isolat yang lain tidak menunjukkan keadaan yang sama dimana rasio amilolitik tidak berbanding lurus dengan aktivitas amiloglukosidase yang dihasilkannya. Hal ini disebabkan oleh faktor-faktor yang memengaruhi sintesis amiloglukosidase seperti perbedaan kesuburan kapang, perbedaan komposisi media agar dengan media produksi, suhu, dan $\mathrm{pH}$, dimana pada saat isolasi, sintesis enzim ekstraseluler yang dihasilkan tidak optimum karena menurut Ilmi \& Kuswytasari (2013), pembentukan enzim ekstraseluler kapang akan lebih baik pada suhu yang lebih rendah dari pada suhu optimum untuk pertumbuhannya (Zambare, 2010). Selain itu aktivitas amilolitik yang terbaca pada saat isolasi hanya merupakan praduga adanya aktivitas amiloglukosdase sebagai salah satu macam enzim amilase yang dapat melakukan aktivitas dengan enzim amilase lainnya ( $\alpha$-amilase dan $\beta$-amilase) secara bersama-sama dan atau sendiri-sendiri, sehingga tidak menunjukkan aktivitas amiloglukosidase secara kuantitatif (Pavezzi et al., 2008).

Berdasarkan Gambar 1 dan 2, masing-masing isolat memiliki aktivitas amiloglukosidase yang berbeda-beda. Pada $\mathrm{pH} 4,5, R$. oryzae memiliki aktivitas amiloglukosidase yang optimum pada suhu $40^{\circ} \mathrm{C}$, yaitu $0,113 \mathrm{U} / \mathrm{ml} / \mathrm{menit}$. A. oryzae memiliki aktivitas amiloglukosidase yang optimum pada suhu $40^{\circ} \mathrm{C}$, yaitu 0,111 $\mathrm{U} / \mathrm{ml} / \mathrm{menit}$. A. niger memiliki aktivitas amiloglukosidase yang optimum pada suhu $45^{\circ} \mathrm{C}$, yaitu $0,124 \mathrm{U} / \mathrm{ml} / \mathrm{menit}$, dan Penicillium sp. memiliki aktivitas amiloglukosidase yang optimum pada suhu $45^{\circ} \mathrm{C}$, yaitu $0,091 \mathrm{U} / \mathrm{ml} / \mathrm{menit}$. Sedangkan $\mathrm{pH}$ optimum aktivitas amiloglukosidase pada suhu $45^{\circ} \mathrm{C}$ masing-masing isolat yaitu $R$. oryzae memiliki aktivitas amiloglukosidase yang optimum pada $\mathrm{pH} 4,5$, yaitu $0,096 \mathrm{U} / \mathrm{ml} / \mathrm{menit}$. A. oryzae optimum pada $\mathrm{pH} 4,0$, yaitu $0,111 \mathrm{U} / \mathrm{ml} / \mathrm{menit} A$. niger optimum pada $\mathrm{pH} 5,0$ dengan aktivitas $0,124 \mathrm{U} / \mathrm{ml} / \mathrm{menit}$ dan Penicillium sp optimum pada $\mathrm{pH} 4,5$ dan 5,5 yaitu 0,098 $\mathrm{U} / \mathrm{ml} / \mathrm{menit}$. Pengukuran aktivitas amiloglukosidase dari keempat isolat pada suhu di bawah suhu $20^{\circ} \mathrm{C}$ dan di atas suhu $60^{\circ} \mathrm{C}$ tidak menunjukkan aktivitas. Hal ini disebabkan karena pada suhu yang terlalu rendah dan terlalu tinggi menyebabkan enzim mengalami denaturasi sebagaimana menurut (Ariandi, 2016), bahwa amiloglukosidase memiliki suhu denaturasi yang lebih tinggi dari $60^{\circ} \mathrm{C}$. Demikian pula pengukuran aktivitas amiloglukosidase pada $\mathrm{pH}$ dibawah 3,0 dan di atas 7,0 menunjukkan aktivitas yang terhenti. Hal ini berarti bahwa pada $\mathrm{pH}$ di bawah 3,0 dan di atas 7,0 amiloglukosidase menjadi inaktif karena mengalami deklinasi (Setiasih et al., 2006; Nangin \& Sutrisno, 2015), sehingga secara umum amiloglukosidase memiliki toleransi terhadap suhu antara $20^{\circ} \mathrm{C}$ sampai $60^{\circ} \mathrm{C}$ dan toleransi terhadap $\mathrm{pH}$ antara 3,0 sampai 7,0. Dari hasil pengukuran aktivitas amiloglukosidase yang telah dilakukan, tampak bahwa aktivitas amiloglukosidase dari masing-masing isolat memiliki stabilitas aktivitas di sekitar $\mathrm{pH}$ dan suhu optimum, sebagaimana menurut Phieter et al. (2020).

Berdasarkan pengukuran aktivitas amiloglukosidasae dari masing-masing isolat kapang, ada hasil pengukuran yang menunjukkan aktivitas yang menyimpang secara teoritis dimana aktivitas amiloglukosidase mengalami penurunan pada suhu maupun $\mathrm{pH}$ pengujian tertentu sebelum aktivitasnya menunjukkan aktvitas yang sesuai secara teoritis. Hal ini dipengaruhi oleh teknis pengukuran aktivitas amiloglukosidase dari masingmasing isolat, misalnya pada pengukuran aktivitas dengan suhu 20 dan $25^{\circ} \mathrm{C}$ digunakan air es sebagai pengontrol suhu sehingga tidak menjamin kestabilan suhu yang semestinya (Kumar \& Satyanarayana, 2009; Rezaul Kar et al., 2017; Pasin et al., 2017). 
Hasil penentuan aktivitas amiloglukosidase tersebut menunjukkan bahwa sumber enzim yang berbeda menghasilkan enzim dengan karakteristik aktivitas yang berbeda pula. Pada umumnya amiloglukosidase memiliki pH optimum 4,0-5,0 dan suhu optimum 40-50 ${ }^{\circ} \mathrm{C}$ (Muchtadi et al., 1992). Perbedaan aktivitas amiloglukosidase dari keempat isolat tersebut dipengaruhi oleh beberapa faktor sehingga tidak berlaku mutlak, dimana produksi enzim dari kapang yang berbeda juga menghasilkan aktivitas yang berbeda, meskipun diujikan pada $\mathrm{pH}$ dan suhu yang sama (Kanti, 2017). Hal ini disebabkan oleh respon genotipik keempat isolat yang berbeda terhadap semua faktor $\mathrm{pH}$, suhu maupun komposisi medium produksi yang digunakan untuk semua isolat, dimana kondisi yang sama tersebut belum tentu cocok untuk keempat isolat dalam membentuk biomassa dan menghasilkan enzim ekstraseluler (amiloglukosidase) sehingga konsentrasi amiloglukosidase yang dihasilkan berbeda-beda dan hal tersebut berpengaruh terhadap kemampuannya menghidrolisis pati.

\section{KESIMPULAN}

Berdasarkan hasil penelitian yang telah diuraikan, dapat disimpulkan sebagai berikut: 1) Isolat kapang asal limbah cair tapioka yang memiliki aktivitas amilolitik sekaligus aktivitas amiloglukosidase diidentifikasi sebagai $R$. oryzae, A. oryzae, A. niger dan Penicillium sp.; 2) Aktivitas amiloglukosidase dari masing-masing isolat berbedabeda dimana aktivitas amiloglukosidase dari $R$. oryzae optimum pada $\mathrm{pH} 4,5$ suhu $40^{\circ} \mathrm{C}$, A. oryzae optimum pada $\mathrm{pH} 4,0$ dan suhu $40^{\circ} \mathrm{C}$, A. niger optimum pada suhu $45^{\circ} \mathrm{C}$ dan Penicillium sp. optimum pada suhu $45^{\circ} \mathrm{C}$, pH 5,0 dan 5,5.

\section{DAFTAR PUSTAKA}

Ariandi. (2016). Pengenalan enzim amilase (alpha-amylase) dan reaksi enzimatisnya menghidrolisis amilosa pati menjadi glukosa. Jurnal Dinamika, 7(1), 74-82.

Devitria, R., \& Sepriyani, H. (2018). Optimalisasi konsentrasi asam klorida pada proses hidrolisis limbah ampas sagu (Metroxylon, sp) terhadap kadar glukosa. Jurnal Analisis Kesehatan Klinikal Sains. 6(2), 37-42.

Ilmi, I. M., \& Kuswytasari, N. D. (2013). Aktifitas enzim lignin peroksidase oleh Gliomastix sp. T3.7 pada limbah bonggol jagung dengan berbagai ph dan suhu. Jurnal Sains Dan Seni Pomits, 2(1), 38-42.

Indrianeu, T., Elgar, \& Singkawijaya, B. (2019). Pemanfaatan limbah industri rumah tangga tepung tapioka untuk mengurangi dampak lingkungan. Jurnal Geografi: Geografi Dan Pengajarannya. 17(2), 3950 .

Kanti, A.-. (2017). Potensi dari kapang Aspergilus niger, Rhizophus oryzae dan Neurospora sitophila sebagai penghasil ezim fitase dan amilase pada substrat ampas tahu. Buletin Peternakan, 41(1), 26.

Karunawan, J., Wati, A. L., Rahmawati, I., Sulhadi, S., Priyanto, A., \& Aji, M. P. (2017). Pemanfaatan limbah ubi kayu dari sisa pengolahan tepung tapioka di Kecamatan Margoyoso Kabupaten Pati menjadi bahan adsorben untuk penjernih air. Prosiding Seminar Nasional Fisika, 6(Oktober), SNF2017-ERE-43- SNF2017-ERE-48.

Kumar, P., \& Satyanarayana, T. (2009). Microbial glucoamylases: characteristics and applications. Critical Reviews in Biotechnology, 29(3), 225-255.

Dwi, M. A. (2017). Analisis faktor-faktor yang mempengaruhi produksi tepung tapioka pada industri skala rumah tangga di Kecamatan Nguntoronadi. Journal Agrista, 5(3), 290-301.

Melliawati, R., Suherman, R. S., \& Subardjo, B. (2006). Pengkajian kapang endofit dari taman nasional gunung halimun sebagai penghasil glukoamilase. Berkala Penelitian Hayati, 12(1), 19-25.

Muchtadi, Palupi, N. ., \& Astawan, M. (1992). Metode Kimia Biokimia dan Biologi dalam Evaluasi Nilai Gizi Pangan Olahan. Pusat Antar Universitas Pangan dan Gizi. Bogor: IPB.

Nangin, D., \& Sutrisno, A. (2015b). Enzim amilase pemecah pati mentah dari mikroba : kajian pustaka raw starch degrading amylase enzyme from microbes : a review. Jurnal Pangan Dan Agroindustri, 3(3), 1032-1039.

Nugroho, A., Effendi, E., \& Novaria, T. (2016). Pengolahan limbah padat tapioka menjadi etanol dengan menggunakan Aspergillus niger, Bacillus licheniformis dan Saccharomyces cerevisiae. Indonesian 
Journal of Urban and Environmental Technology, 7(1), 17-23.

Pasin, T. M., Benassi, V. M., Heinen, P. R., Damasio, A. R. de L., Cereia, M., Jorge, J. A., \& Polizeli, M. de L. T. de M. (2017). Purification and functional properties of a novel glucoamylase activated by manganese and lead produced by Aspergillus japonicus. International Journal of Biological Macromolecules, 102, 779-788.

Pavezzi, F. C., Gomes, E., \& Da Silva, R. (2008). Production and characterization of glucoamylase from fungus Aspergillus awamori expressed in yeast Saccharomyces cerevisiae using different carbon sources. Brazilian Journal of Microbiology, 39(1), 108-114.

Pedersen, H., Beyer, M., \& Nielsen, J. (2000). Glucoamylase production in batch, chemostat and fed-batch cultivations by an industrial strain of Aspergillus niger. Applied Microbiology and Biotechnology, 53(3), 272-277.

Phieter, A. C., Chrisnasari, R., \& Pantjajani, T. (2020). Karakterisasi Enzim Pemecah Pati dari Malt Serelia. Keluwih: Jurnal Sains Dan Teknologi, 1(1), 38-48.

Putra Adnyana, I., Hartiati, A., \& Arnata, I. (2015). Pengaruh suhu dan konsentrasi enzim amiloglukosidase pada proses sakarifikasi produksi gula cair pati ubi gadung (Dioscorea hispida Dennts). Jurnal Rekayasa dan Manajemen Agroindustri, 3(2), 140-151.

Rahayu, M. A., Sulistyaningtyas, A. R., \& Darmawati, S. (2019). Isolasi Bakteri Hidrolitik Penghasil Enzim Amilase dari Limbah Industri Tapioka. Prosiding Seminar Nasional, 2, 147-155.

Rezaul Kar, K. M., Husaini, A., \& Tasnim, T. (2017). Production and Characterization of Crude Glucoamylase from Newly Isolated Aspergillus flavus NSH9 in Liquid Culture. American Journal of Biochemistry and Molecular Biology, 7(3), 118-126.

Setiasih, S., Wahyuntari, B., \& Apriliani, D. (2006). Karakterisasi Enzim Alpha -Amilase Ekstrasel dari Isolat Bakteri Termofil SW2. Jurnal Kimia Indonesia, 1(1), 22-27.

Sopandi, T., \& Wardah. (2014). Mikrobiologi Pangan. Yogyakarta: Penerbit Andi.

Sunaryanto, R., \& Marasabessy, A. (2016). Optimalisasi media produksi amiloglukosidase menggunakan fermentasi media padat. Jurnal Bioteknologi \& Biosains Indonesia (JBBI), 374, 1-7.

Sutikno, Marniza, Selviana, \& Musita, N. (2016). Pengaruh konsetrasi enzim selulase, $\alpha$-amilase dan glukoamilase terhadap kadar gula reduksi dari onggok. Jurnal Teknologi Industri Dan Hasill Pertanian, 21(1), 1-12.

Xiao, Z., Storms, R., \& Tsang, A. (2006). A quantitative starch-iodine method for measuring alpha-amylase and glucoamylase activities. Analytical Biochemistry, 351(1), 146-148.

Zambare, V. (2010). Solid-State Fermentation of Aspergillus oryzae for Glucoamylase Production on Agro residues. International Journal of Solid-State, 4, 16-25. 